University of South Florida

DIGITAL COMMONS

Digital Commons @ University of

@ UNIVERSITY OF SOUTH FLORIDA

South Florida

The Inside, Outside, and Upside Downs of

Children's Literature: From Poets and Pop-ups

to Princesses and Porridge

Teaching and Learning

$1-1-2016$

\title{
Chapter 08: Beyond the Page and Behind the Scenes
}

Jenifer Jasinski Schneider

University of South Florida, jschneid@usf.edu

Follow this and additional works at: https://digitalcommons.usf.edu/childrens_lit_textbook

Part of the Education Commons

\section{Recommended Citation}

Schneider, Jenifer Jasinski, (2016). Beyond the Page and Behind the Scenes. In The Inside, Outside, and Upside Downs of Children's Literature: From Poets and Pop-ups to Princesses and Porridge (p. 220-251). http://dx.doi.org/10.5038/9780977674411.ch8

This Book Chapter is brought to you for free and open access by the Teaching and Learning at Digital Commons @ University of South Florida. It has been accepted for inclusion in The Inside, Outside, and Upside Downs of Children's Literature: From Poets and Pop-ups to Princesses and Porridge by an authorized administrator of Digital Commons@ @niversity of South Florida. For more information, please contact digitalcommons@usf.edu. 


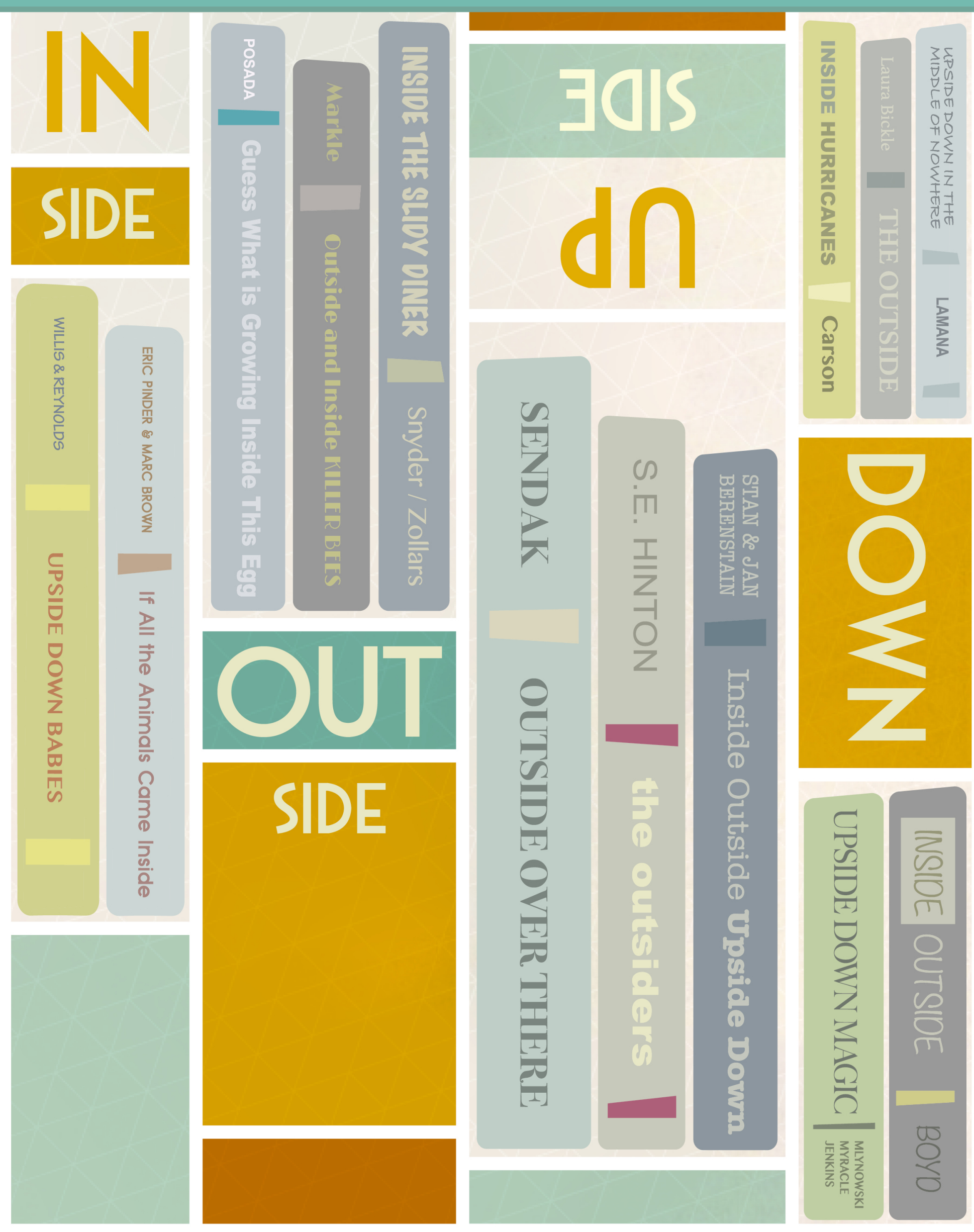

\section{THE INSIDE, OUTSIDE, AND UPSIDE DOWIS From Poets and Pop-ups to OF CHILDREN'S LITERATURE Princesses and Porridge}




\section{The Inside, Outside, and Upside Downs of Children's Literature: From Poets and Pop-ups to Princesses and Porridge}

Jenifer Jasinski Schneider, Ph.D. 
Copyright

Published by The University of South Florida Library, 4202 E. Fowler Avenue, Tampa, FL 33620.

Copyright (C2016 by Jenifer Jasinski Schneider. All rights reserved.

\section{(c) $(1) \odot$}

This work is licensed under a Creative Commons Attribution-NonCommercial-NoDerivatives 4.0 International License.

Author and Editor in Chief: Jenifer Jasinski Schneider

Editorial Director: Monica Metz-Wiseman

Media Project Manager and Producer: Christine Brown

Video Producers and Editors: Jared Brown, Jason Su, Ian Crenshaw, Jessica Brennen,

Diana Trueman, Jeremy Willis

Art Director: Stephanie Rivera

Illustrators and Multimedia Designers: William Tillis and Elise Michal

Copyright Coordinator: LeEtta M. Schmidt

Open-Access Editor: Jason Boczar

Editorial Manager: Carol Ann Borchert

Editorial Project Manager: Chelsea Johnston

Cover image book credits:

Upside Down Babies by Jeanne Willis and Adrian Reynolds (C)2013 Andersen Press; If All the Animals

Came Inside by Eric Pinder and Marc Tolon Brown (C)2012 Little, Brown and Company; Guess What Is Growing Inside This Egg by Mia Posada (C2007 Millbrook Press; Outside and Inside Killer Bees by Sandra Markle (C)2004 Walker \& Co.; Inside the Slidy Diner by Laurel Snyder and Jaime Zollars (C)2008 Tricycle Press; Outside Over There by Maurice Sendak (C)1989 HarperCollins; The Outsiders by S.E. Hinton, original cover art by Robert Hunt (C1967 Viking Press. Mass Market edition (C1997 Speak; Inside Outside Upside Down by Stan and Jan Berenstain (C1968 Random House; Upside Down Magic by Sarah Mlynowski, Lauren Myracle, and Emily Jenkins (C)2015 Scholastic Press; Inside Outside by Lizi Boyd (C)2013 Chronicle Books; Inside Hurricanes by Mary Kay Carson (C)2010 Sterling; The Outside by Lauren Bickle (C)2013 Houghton Mifflin Harcourt; Upside Down in the Middle of Nowhere by Julie T.

Lamana (C)2014 Chronicle Books.

Library of Congress Cataloging-in-Publication Data

Schneider, Jenifer Jasinski, 1968-

The Inside, Outside, and Upside Downs of Children's Literature: From Poets and Pop-ups to Princesses and Porridge / Jenifer Jasinski Schneider.

ISBN- 978-0-9776744-1-1 eBook

ISBN- 978-0-9776744-2-8 print

The Internet addresses listed in the text were accurate at the time of publication. 


\section{HOTTOPICSANDCURIOUSQUANDARIES}

SECTION2 


\section{8 \\ BEYOND THE PAGE AND BEHIND THE SCENES \\ (WRITING, PUBLISHING, AND MARKETING CHILDREN'S LITERATURE: BOOKS, CINEMA, CARTOONS, TOYS AND APPS]

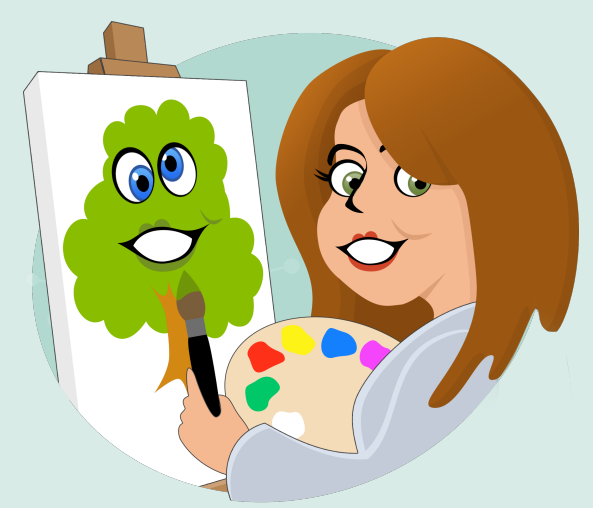

Since 1998, I have served as the Director of an annual literature conference for children. The Children's Literature Collection of Know-how (CLICK) provides an opportunity for professional authors and illustrators to speak to youth and provide tips for writing and drawing (Figure 8.1). In addition to learning from professionals, the children and youth share their own writing with each other and receive feedback from the audience (Figure 8.2). The attendees work with a journalist to create the CLICK blog (Figure 8.3).

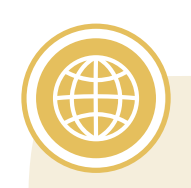

Children's Literature Collection of Know-how:

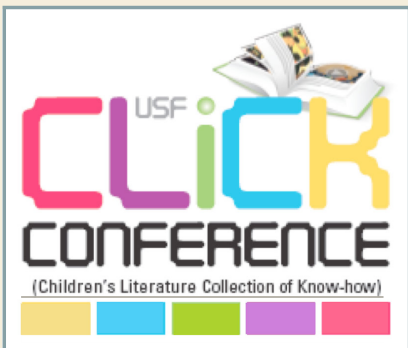

Website: www.coedu.usf.edu/syac

Facebook:

- https://www.facebook.com/ ClickChildrensLiteratureCollectionOfKnowHow

- https://www.facebook.com/Suncoast-YoungAuthors-Celebration-Alumni-550145618363135/ timeline/

Twitter: https://twitter.com/usfclick

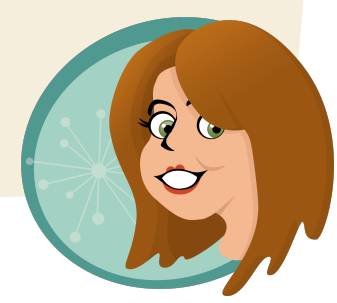

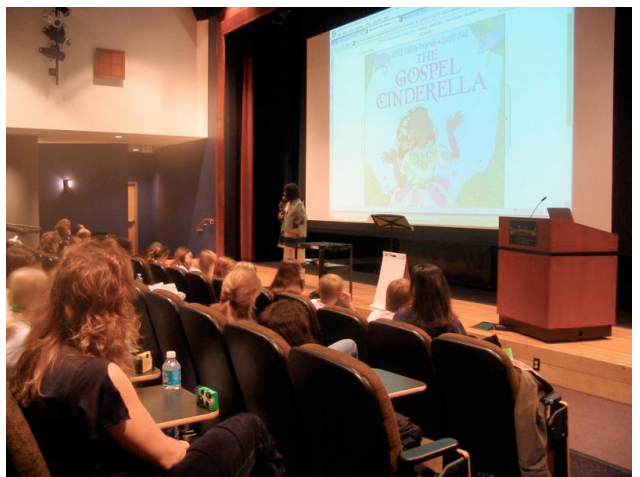

Figure 8.1

The Children's Literature Collection of Knowhow (CLICK) is an annual conference featuring authors and illustrators. Joyce Carol Thomas presented to the crowd of children and adults in 2006. In the photo, she shares images from The Gospel Cinderella as she talks about her writing process. The Gospel Cinderella by Joyce Carol Thomas and illustrated by David Diaz, 2004, New York, NY: Amistad. Photo copyright 2006 by Jenifer Schneider.

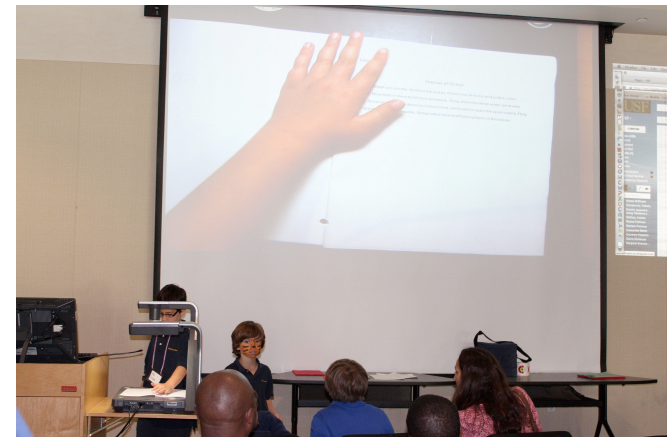

Figure 8.2

Attendees share their writing during a break out session at the CLICK Conference. Photo copyright 2014 by Jenifer Schneider.

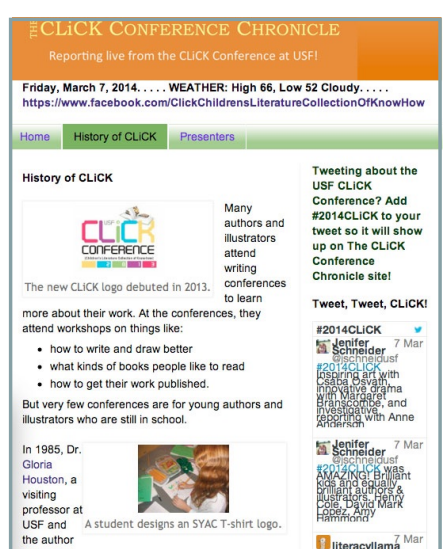

Figure 8.3

Youth work with journalist-in-residence, Anne Worthwine Anderson, to create the CLICK Chronicle, a conference blog. Photo copyright 2015 by Jenifer Schneider. 
They also participate in several breakout sessions that showcase their artistic responses to the books featured during the conference.

Drawing (Figure 8.4 and Figure 8.5);

Bookmaking (Figure 8.6);

Filmmaking (Figure 8.7);

Performance activities (Figure 8.8).

Over the years, approximately 10,000 youth from over 75 public, private, and home schools have attended the conference. In addition, hundreds of parents, teachers, librarians and volunteers have chaperoned.
Figure 8.4

Children create guerilla art in response to reading books and listening to the author and illustrator talks. Photo copyright 2015 by Jenifer Schneider.

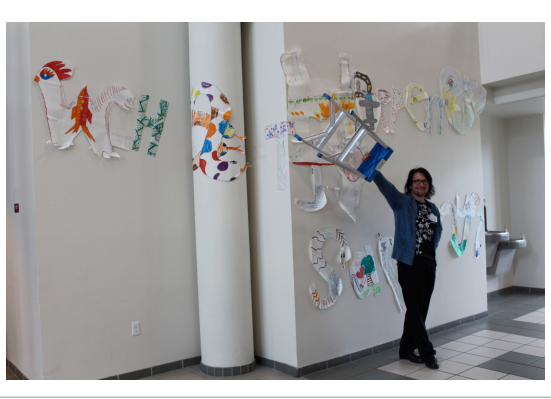

Figure 8.5

CLICK artist-in-residence, Csaba Osvath, poses with the guerilla art that he helped the participants create (http://www.csabaosvath.com/). Photo copyright 2015 by Jenifer Schneider.

Figure 8.6

Students create blank books to take home from the CLICK Conference. Photo copyright 2015 by Jenifer Schneider.

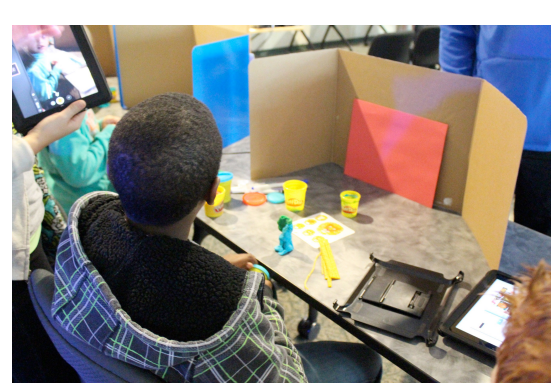

Figure 8.7

Students use Play-doh and iPads to create stop-motion versions of the books they read during the CLICK Conference. Photo copyright 2015 by Jenifer Schneider.

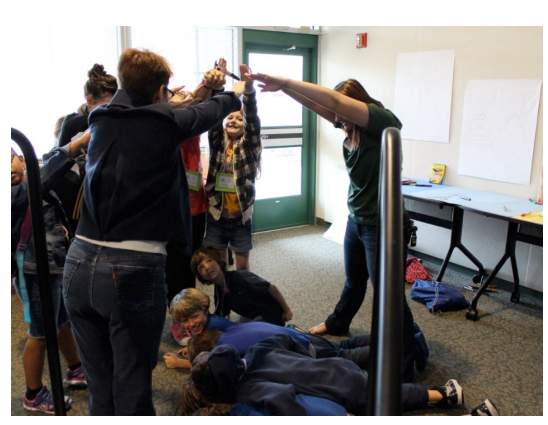

Figure 8.8

Dramatist, Margaret Branscombe, works with children during the CLICK Conference. Students use tableau and other theater games to revisit the books discussed by the CLICK authors and illustrators. For more information about Margaret and her techniques, visit http://www.learnthroughdrama.com/. Photo copyright 2015 by Jenifer Schneider.

With all those children and adults, you might be surprised to learn that every year, without fail, they ask the guest authors and illustrators the same exact questions:

- How did you learn to write or draw?

- Where do you get your ideas?

- How do I get published? 
In this chapter, I further explore children's literature beyond the page and behind the scenes. I take a look at children's book authors and illustrators to understand the nature of their processes. I link to resources for aspiring writers and illustrators and provide insider perspectives on the publication process. I also connect the origins of ideas with the marketing of movies, toys, games, and apps in order to provide an expansive view of children's literature markets beyond the books. As you will discover, no aspect of children's literature is as simple, as glamorous, or as textual as it may seem.

\section{The Work of Authors and Illustrators: Learning to Write or Draw}

"A work of art is essentially the internal made external, resulting from a creative process operating under the impulse of feeling, and embodying the combined product of the poet's perceptions, thoughts, and feelings" (Abrams, 1953, p. 22). Much of the attention on children's literature focuses on the work of art-the written text or the illustrated image. Readers read the resulting products. Critics dwell on text and images. In this section, I explore the creation of these works of art-the internal made external.

Professional writers and illustrators of children's and young adult literature often articulate their "tools of the trade" and share insightful reflections about their creative processes. In turn, their tips provide their readers and fans with specific methods and suggestions that can be imitated.

Here is a collection of resources for aspiring writers. Warning! These articles contain conflicting ideas:

- 8 Habits of Highly Successful Young Adult Fiction Authors: http://www.theatlantic.com/entertainment/archive/2013/10/the-8-habits-of-highly-successful-youngadult-fiction-authors/280722/

- How to Write a Picture Book: http://www.buzzfeed.com/macbarnett/how-to-write-a-picture-book-io66\#.ck4mkDrg8

- C.S. Lewis on the Three Ways of Writing for Children and the Key to Authenticity in All Writing by Maria Popova: http://www.brainpickings.org/2014/06/18/c-s-lewis-writing-for-children/

- The Hundred Best Websites for Writers in 2015:

http://thewritelife.com/10o-best-websites-for-writers-2015/\#.2f65qk:kGK2

- Writing Young Adult Fiction for Dummies:

http://www.dummies.com/how-to/content/writing-young-adult-fiction-for-dummies-cheat-shee.html

- Writing Children's Books for Dummies:

http://www.dummies.com/how-to/content/writing-childrens-books-for-dummies-cheat-sheet.html

- How To Create A Fantastic Picture Book:

https://www.writersandartists.co.uk/writers/advice/327/dedicated-genre-advice/writingfor-children/

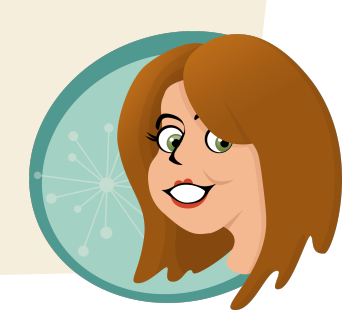


Some writers engage in familiar routines that can be approximated by the general public, but others have developed habits that may be impractical for most of us (e.g., Roald Dahl wrote in a backyard hut). Professional methods are not recipes for guaranteed success, but they are practices that may take the mystery, and often the misery, out of writing words or making art.

\section{The Writers}

Several years ago I surveyed children's book authors and illustrators to get a sense of their backgrounds, educational training, and approaches to children's book creation (Schneider, 2010). Eighty-five people responded to the anonymous survey and I synthesized their reflections on several components of the process of writing children's books. Below, I share their responses and highlight major points with examples from other writers who have publically revealed elements of their process.

Funding for the survey research was provided by the International Reading Association, Elva Knight Research Grant.

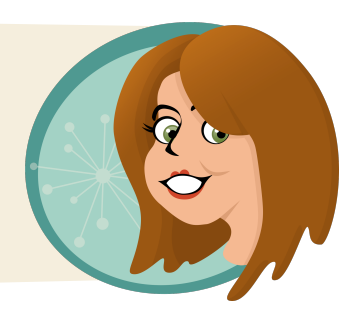

Forms and Feedback. Although we may have romantic visions of authors as spending their days writing in cafes and sipping coffee (see Mo Willems writing in a Paris cafe http://www.cbsnews.com/news/for-kids-book-author-mo-willems-childhood-is-an-awful-time/), the authors I surveyed consistently indicated that their most predominant form of writing was email followed by letters or formal correspondence. Remember, most authors (and illustrators) are independent contractors who must manage the business end of children's book creation along with the creative components. 
When I book authors or illustrators for the CLICK Conference, I send an email to determine the person's availability. Once we agree to the terms of the presentation, then I email a contract, which the creator must read, sign, and return along with tax forms and other documentation. The authors/illustrators typically book their own air fare and hotel room and then they must obtain reimbursement from the CLICK Conference (more documentation and email correspondence). We exchange emails or schedule phone calls to discuss the nature of the presentation, their needs for materials (microphones, easels, markers, chair and room arrangement, etc.)

I work with the university bookstore to manage the sale of books; however, when authors and illustrators make school visits, they have more of a role in the book sale process. They select the books they want to sell, but often these books are not ready for sale or there is some snag in distribution. Therefore, they must contact the publisher to intervene and push the process along.

On the day of the CLICK Conference, the authors and illustrators present to groups of children, interact with attendees, and sign autographs. I have observed illustrators using "down time" to sketch illustrations or write notes. A school visit can take 2 or more days out of the week (plus the prep and follow up). The authors' and illustrators' days are filled with school visits and talks to promote their books and increase sales which leaves very little time for creating new ones.

None of what I have just described includes the many ways in which the authors and illustrators communicate with editors, graphic designers, book production staff, etc. To create a book, the author and illustrator is involved in much more than "creation."

As for their creative writing efforts, the authors most frequently write in narrative and poetic genres. The authors write in home offices and they rarely "collaborate" in the co-writing sense of the word. Of course some of the authors participate in writing groups, or they consult with editors, but they do not consider their writing process to be collaborative. Authors receive feedback and then make further writing decisions on their own.

Some authors use writing groups and various organizations provide networking opportunities for people who want to write books for children.

- Society of Children's Book Writers and Illustrators http://www.scbwi.org/ frequently-asked-questions/.

- Children's Book Author Meetups http://childrens-book-authors.meetup.com/

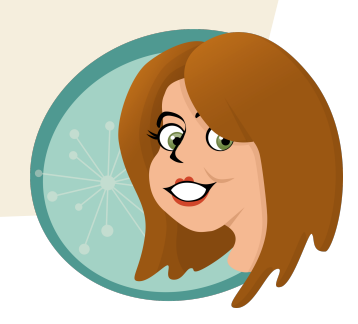


Processes and Procedures. If you were to observe a writer during the active creation of a text, you would not witness much action beyond typing on a keyboard or letter formation on a notepad. The behaviors of writers are not grandiose and magnificent; they are often subtle. For example, you might see a writer create several revisions of the same text. The writer might play with alternative words or sayings, or create alternative beginnings, middles, and ends.

Often, a writer's work is invisible and unrelated to the act of writing. Writers may revise their work inside their heads, which leaves their bodies free to behave in other ways. Writers can work while they are painting, listening to music, driving a car or taking a shower. Some authors have to write while lying down on a sofa or in bed. Others need special objects around them (e.g., Roald Dahl sat in big chair, covered his feet with a sleeping bag, and surrounded himself with travel souvenirs and photos-Figure 8.9). The "quirks" of writers are often humorous and unusual but they remind us that writing is a compilation of the writer's entire being. Writing is a mental, emotional and physical act.

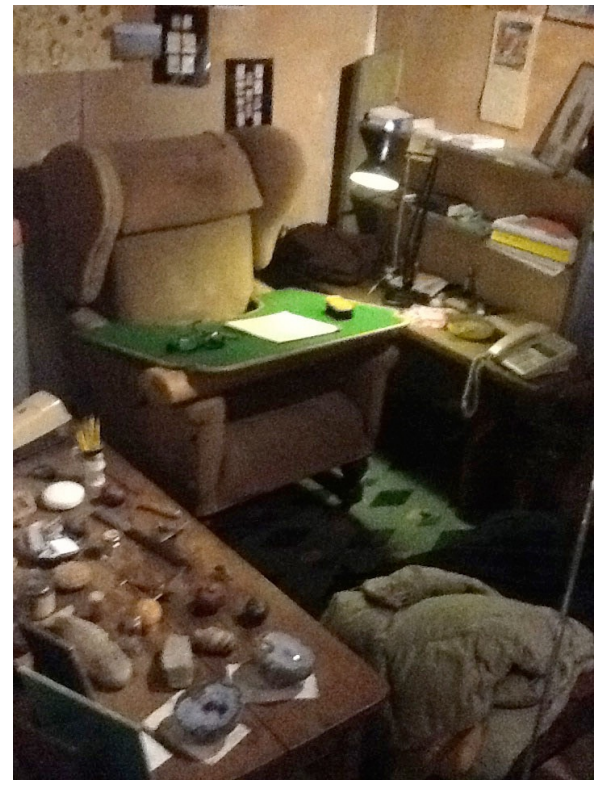

Figure 8.9

Roald Dahl's hut at the Road Dahl Museum and Story Centre. Photo copyright 2013 by Jenifer Schneider.

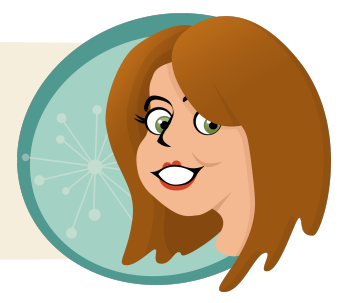


The authors I surveyed revealed that they mentally plan for writing, rarely using webs or organizers, but occasionally creating lists or outlines of their texts. The authors do not focus on fonts or layout, nor do they focus on "correctness." Font, color, graphics, and other visual aspects of children's literature are not considerations in the writing process because book design and artwork are separate procedures. Instead, the authors stated that they attend to language and ideas. They value other writing skills that develop their personal writing styles such as reading good examples and understanding audience. The authors revealed that they rely on editors to catch and correct grammar and mechanics errors. They also acknowledge the contributions of copy-editors in "cleaning up" their writing.

Authors hardly rely on the writing strategies most people learn in school (Video 8.1). Watch Kate DiCamillo and Katherine Paterson dismiss common instructional strategies as they discuss their writing processes. https://www.youtube.com/watch? $\mathrm{v}=$ GprltUiL-YQ

Also, the following writers share tips and tricks:

- Mem Fox: http://memfox.com/for-writers-hints/for-writer-hints/

- Pat Mora: http://www.patmora.com/tips/

- Emma Walton Hamilton: http://emmawaltonhamilton.com/the-6-common-

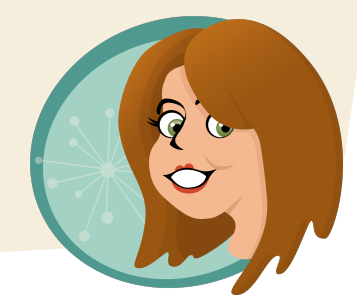

Video 8.1 The Evolution of an Author's Manuscript: Luna by Julie Anne Peters http://www.kaltura.com/tiny/zul3z

\section{THE EVOLUTION OF AN AUTHOR'S MANUSCRIPT: LUNA BY JULEE ANNE PETERS}


Writing Instruction and Training. Most of the authors stated that they learned writing skills in high school or college and they learned how to refine their texts by reading and analyzing their teachers' written comments. The authors frequently stated that writers must learn to "accept feedback and criticism." They suggested that those who aspire to become writers should "read extensively in order to know the field" and, given the amount of rejection in children's book publishing, new writers should "choose the career path only if writing is a passion."

Interpreting written feedback might seem like a no-brainer but it is actually good advice. For some reason many people do not learn this strategy. In addition, it's hard to do. Writers must understand the reviewer's advice and then figure out how to act on it.

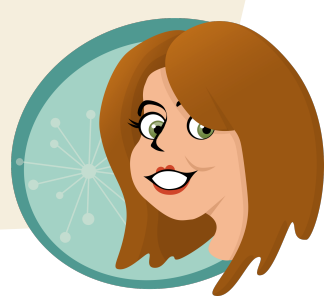

The authors I surveyed unanimously valued reading and writing as tools for improving writing skills. They suggested that aspiring authors read quality examples and study the writing styles of other published authors. One author stated, "Read, read, read." Another one wrote, "Write, write, write."

Here is a short list of authors and illustrators who share tips and tricks.

I think these resources are particularly helpful:

- Doreen Marts: http://www.creativebloq.com/illustration/5-tips-illustratingchildrens-book-5132983

- David MacIntosh: http://www.theguardian.com/childrens-bookssite/2014/mar/11/david-mackintosh-top-10-illustration-and-design-tips

- Jim Harris: http://www.jimharrisillustrator.com/ChildrensBooks/ TipsforIllustrators.html

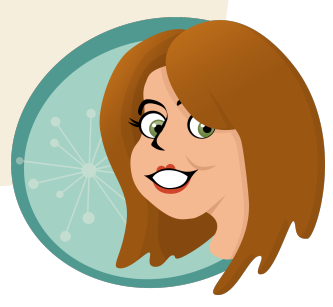


Although many of the authors earned college degrees in diverse fields such as psychology, business, and education, most of the authors had backgrounds in writing or took college courses in creative writing. There are several colleges and universities that offer specific programs in "Writing for Children."

- Columbia University School of the Arts offers courses in Writing Children's Books. http://arts.columbia.edu/summer/writing/course/childrens-books

- Hamline University offers an MFA in Writing for Children and Young Adults. http://www.hamline.edu/cla/mfac/

- Hollins University offers an MFA in Children's Book Writing \& Illustrating. https://www.hollins.edu/academics/graduate-degrees/childrens-book-writing-illustrating/

- Lesley College offers an MFA degree in Writing for Young People. http://www.lesley.edu/master-of-fine-arts/creative-writing/low-residency/writing-for-young-people/

- Simmons College offers an MFA in Writing for Children. http://www.simmons.edu/academics/graduate-programs/writing-for-children-mfa

- Vermont College of Fine Arts offers an MFA in Writing for Children \& Young Adults. http://vcfa.edu/wcya

Through my survey, I attempted to capture and synthesize successful writers' processes in relation to their education, training, and writing strategies. Outside of the advice to "read" and "write," the authors communicated many other unique suggestions. Rather than revealing a blueprint of effective writing strategies, the survey responses reiterated the fact that writing is an idiosyncratic process. In other words, there isn't one way to write a children's book.

\section{The Illustrators}

Illustrators share many similarities with the writers of children's literature. Illustrators work in their studios and they function as independent contractors. Many illustrators also work as contract employees for publishers. Just like children's book authors, the illustrators manage the business components of their careers and they must engage in correspondence, contract negotiation, billing, public relations, and marketing. Hiring an agent and management personnel can relieve some of the publication responsibilities; however, hiring people costs money. 
Forms and Feedback. Most

illustrators have worked in formal art settings, gaining experiences in corporate art production before working as freelance children's book illustrators. For example, many illustrators have experience creating greeting cards, film animation, or producing artwork for magazines (Figure 8.10).

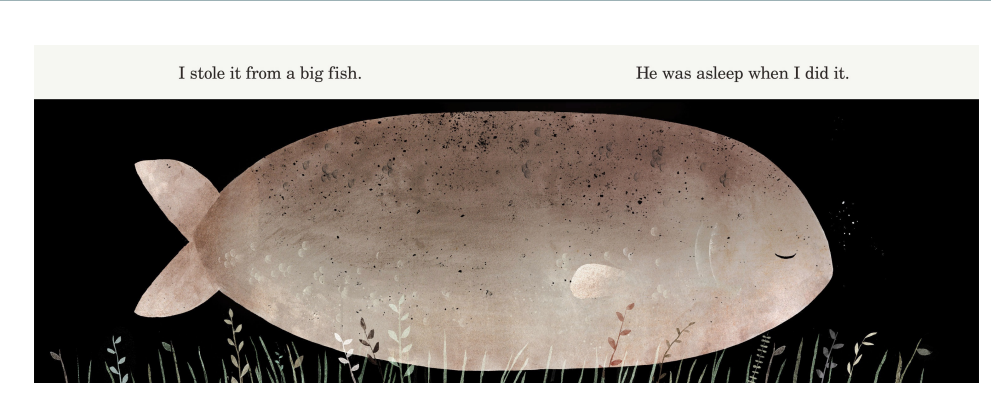

Figure 8.10

Jon Klassen worked as a film animator. His book, This is Not My Hat, won the Caldecott Medal. Image from This Is Not My Hat by Jon Klassen, 2012, Somerville, MA: Candlewick Press. Copyright 2012 by Jon Klassen.

The reading public is generally unaware that children's book writers and illustrators do not work together when developing children's books. In addition, publishers do not want writers to find their own illustrators. Of course, there are some illustrators who are also talented writers, but, generally, the writer writes and the illustrator illustrates, leaving each person to create spaces for interpretation in the final product.

Generally, the author and illustrator come together through the publisher's production staff. Editors work with the writers and different editors/art directors work with the illustrators. The publishers match the artist to a particular text. The art director (or similar type of personnel) is the person who selects the appropriate illustrator for a book project. The art director communicates with the illustrator and "directs" his/her visual work, providing feedback on the evolution of the product.

Processes and Procedures. For illustrators, art making is a mental, emotional, and physical act. Although many people would think about illustration as a primarily physical process, the artistic process is an embodied reaction to thinking and visualization.

Illustrators explore ideas on canvases using various media and mock-ups, but their processes capture mental imagery. As with the writers, an observer can't see visualizing, but an observer can see composing and revision.

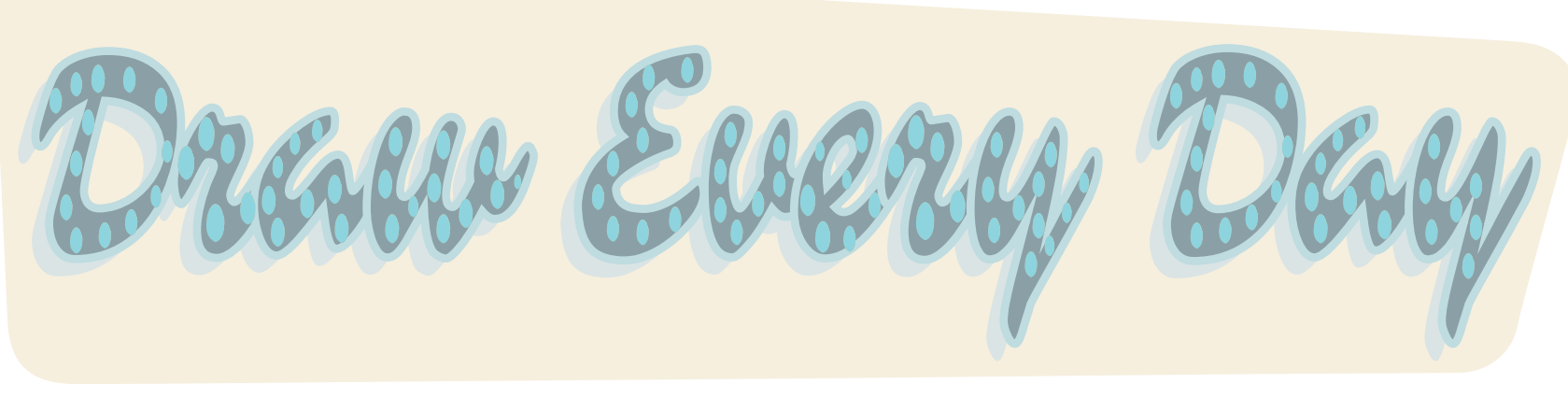


Some illustrators use sketchpads; some compile photographic images; others draw on the computer. Most artists work in a studio or on a large desk on which they can assemble materials and maintain works in progress because an illustrator's work is not always movable, neat, or small. Again, an illustrator's process is idiosyncratic.

For an excellent discussion on the importance of an artist's sketchpad, read "Chris Raschka: The Habits of an Artist” http://www.hbook.com/2012/o6/ creating-books/chris-raschka-the-habits-of-an-artist/\#__

For a glimpse at the variety of artists' desks and workspaces, read, "The Creative and Colorful Desks of Children's Book Illustrators” by Jordan G. Teicher. http://www.slate.com/blogs/behold/2015/o8/10/ jake_green_photographs_emerging_children_s_illustrators_in_his_book_the.html

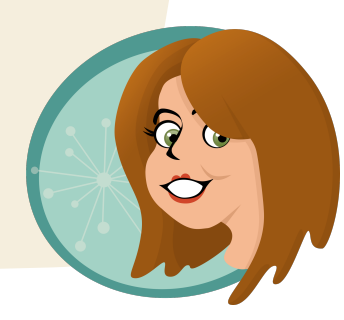

Once an illustrator is selected for a children's book, he or she creates a rough sketch of the book illustration. These rough sketches or dummies provide the editor with enough detail regarding the artist's point of view, color scheme, page layout, and illustrative focus to understand the overall look and feel of the book. Based on the editor's feedback and the publisher's specific production process, the artist makes changes and continues the process until the final images are approved.

Jane Massy describes the book development process:

http://www.artistsandillustrators.co.uk/how-to/family-art/281/how-to-illustratea-childrens-book

The Children's Literature Research Collection at the University of Minnesota presented an online exhibit about the engineering of a picture book, featuring Melissa Sweet’s “Balloons Over Broadway.” http://gallery.lib.umn.edu/ exhibits/show/balloons-over-broadway

Allison Jay describes the book illustration process in this blog post: https://kathytemean.wordpress.com/2014/05/17/illustrator-saturday-alison-jay/

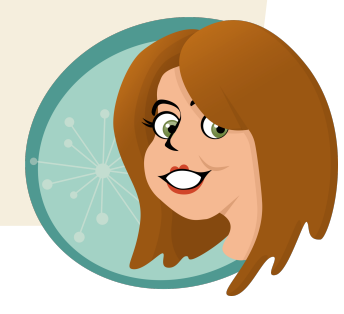


Art Instruction and Training. Although many people might assume children's book art is predominantly cartoon art or digitized illustration, children's book artists work in all forms of media: collage, gouache, pencil, watercolor, oil, paper, construction, and pastels. An artist may use one type of media and consistently work in one particular style. Other successful artists use multiple media and create illustrations in many different styles.

Children's book illustrators attend top design schools. Top design schools teach children's book illustration.

- Pratt Institute

(https://www.pratt.edu/the-institute/);

- Rhode Island School of Design

(http://www.risd.edu/);

- School of the Art Institute of Chicago

(http://www.saic.edu/index.html)

- Hollins University

(https://www.hollins.edu/);

- Ringling College of Art and Design

(http://www.ringling.edu/);

- Columbia University School of the Arts

(http://arts.columbia.edu/);

- Simmons College of Arts and Sciences

(http://www.simmons.edu/academics/schools/college-of-arts-and-sciences).

The quality of children's book illustrations are so high, illustrations are shown in galleries and museums across the world.

- The Eric Carle Museum of Picture Book Art (http://www.carlemuseum.org/) collects, preserves, presents, and celebrates picture books and picture book illustrations from around the world (Figure 8.11).

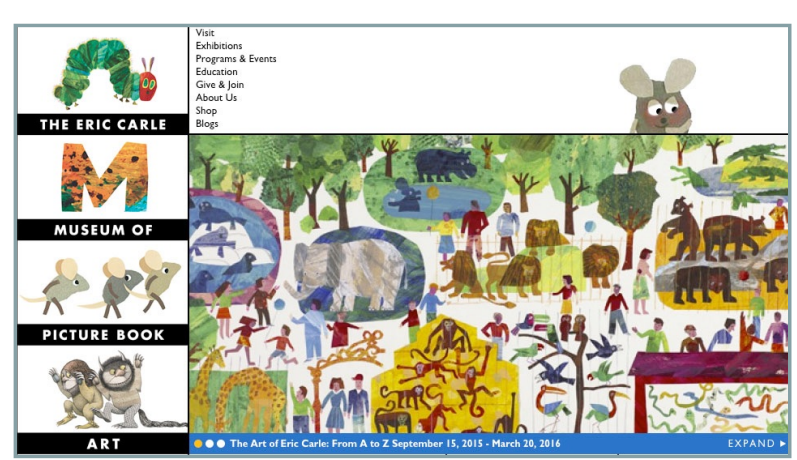

Figure 8.11

The Eric Carle Museum of Picture Book Art (http://www.carlemuseum.org/). 
- The Mazza Museum (http://www.mazzamuseum.org/) promotes literacy and enriches the lives of all people through the art of children's literature. Located on the campus of the University of Findlay, the museum features thousands of pieces of art from hundreds of artists.

- The de Grummond Children's Literature Collection (http://digilib.usm.edu/cdm/ landingpage/collection/degrum) at the University of Southern Mississippi Collection features American and British children's literature, historical and contemporary.

- The Kerlan Collection at the University of Minnesota (https://www.lib.umn.edu/clrc/kerlancollection) includes original illustrations from various artists and historical illustrations as well.

- The Victoria and Albert Museum (http://www.vam.ac.uk/content/articles/n/national-art-librarychildrens-literature-collections/) in the UK holds over 100,000 books from the 16th entry to the present day.

- The Norman Rockwell Museum (http://www.nrm.org/) hosts a Distinguished Illustrator Series.

- Maurice Sendak's illustrations are exhibited in the Rosenbach Museum in Philadelphia, PA (https://www.rosenbach.org/learn/collections/mauricesendak-collection) (Figure 8.12). Sendak was also featured on the American Masters series on PBS (http://www.pbs.org/wnet/americanmasters/mauricesendak-about-maurice-sendak/701/).

- Seven Stories is the National Centre for Children's Books in the UK (http://www.sevenstories.org.uk/). The collection features authors and illustrators, thousands of books, and rotating exhibits.

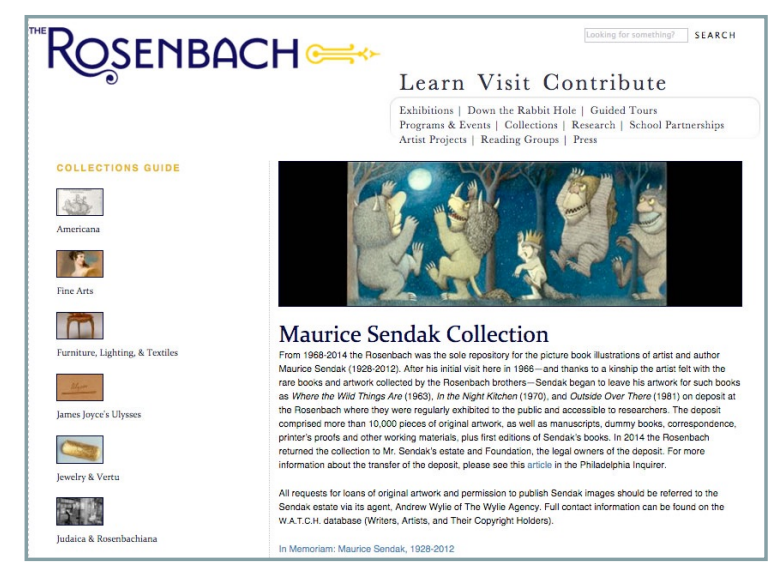

Figure 8.12

The Maurice Sendak Collection at the Rosenbach Museum

(https://www.rosenbach.org/learn/ collections/maurice-sendak-collection).

- Trinity College Dublin Library holds over 150,000 children's books. The collection is accessible through the National Collection of Children's Books (https://nccb.tcd.ie/about) and features periodic exhibits such as Upon the Wild Waves: A Journey through Myth in Children's Books (https://www.tcd.ie/Library/about/exhibitions/wild-waves/). 
In contrast to the laborious methods of illustration that were in place during the early years of children's literature publication (Video 8.2), modern digitalization and printing processes have created countless possibilities for children's book illustration.

The following online resources provide viewers with access to the illustration process of many children's book artists. Illustrators use these websites to network and showcase their work. Some of the sites provide opportunities for continuing education as well:

- Artists \& Illustrators- how to guide http://www.artistsandillustrators.co.uk/how-to

- Children's Illustrators http://www.childrensillustrators.com/

- Children’s Books Guide http://childrensbooksguide.com/illustrators

- Illustration http://www.illustrationweb.us/artists

- Artists Network http://www.artistsnetwork.com/

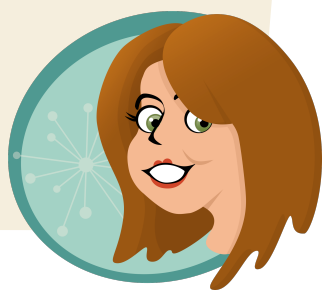

Video 8.2 Chromolithography and Early Methods for Color Illustrations http://www.kaltura.com/tiny/lnlwj

\section{CHROMOLITHOGRAPHY \& EARLY METHODS FOR COLOR ILLUSTRATIONS}


There is no particular style or media that is more successful than others. Children still prefer color rather than black and white. And they tend to gravitate toward realistic, detailed illustration rather than sparse, surreal interpretive scenes. But there are many exceptions to these general preferences (Figure 8.13). Yes, grocery store books (common, lower-quality books) may have similar looks, but the children's books that have literary value, artistic value, maintain a reader's interest, and stand the test of time are illustrated from a broad spectrum of styles and media. Any medium can be found in children's literature.

Acrylics (Figure 8.14)

Crayon (Figure 8.15)
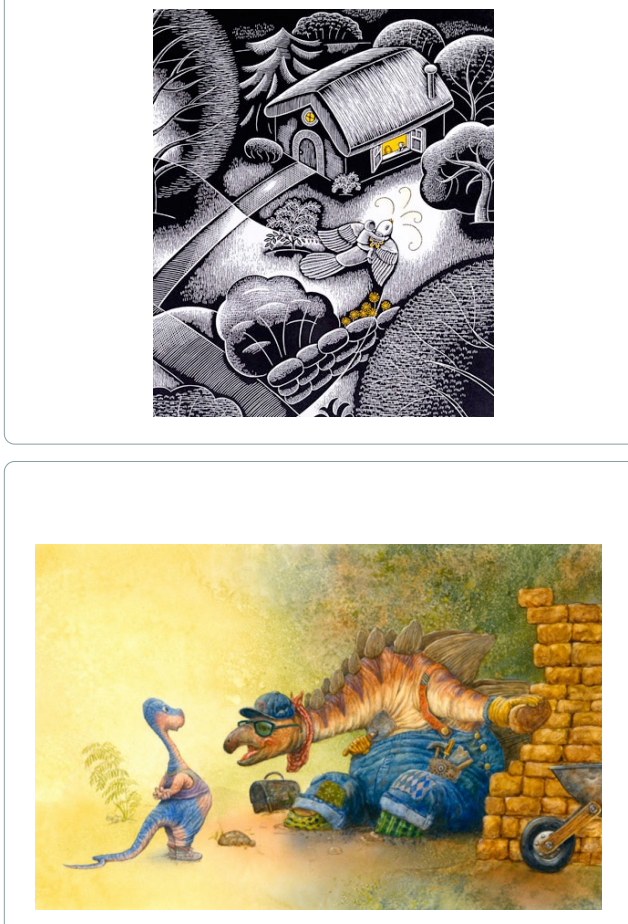

Figure 8.14

Acrylic paints are water-soluble, synthetic paints. They can have a gloss or matte finish and a thin or thick opacity. Jim Harris describes the pros and cons of painting with acrylics (http:// www.jimharrisillustrator.com/ChildrensBooks/ Books/threelittledinos.html\#oilpainting). He used acrylic and oil paint to create his book, The Three Little Dinosaurs. Image from The Three Little Dinosaurs by Jim Harris, 1999, Gretna, LA: Pelican Publishing. Copyright 1999 by Jim Harris.

Beth Krommes' scenic, folk-art illustrations are predominantly black and white, but they capture readers' attention and draw them into the story. Swanson and illustrated the Night by Susan Marie New York, NY: HMH Books for Young Readers. Illustration copyright 2009 by Beth Krommes.

Figure 8.15

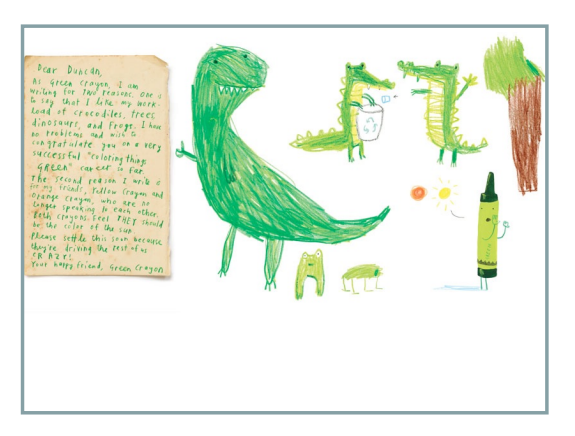

Oliver Jeffers uses all types of media, but The Day the Crayons Quit is an example of crayon illustration. You will enjoy his website

(http://oliverjeffersworld.com/) and his short film about his artistic process (https://vimeo.com/ 57472271). The Day the Crayons Quit by Drew Daywalt and illustrated by Oliver Jeffers, 2013, New York, NY: Philomel. Illustration copyright 2013 by Oliver Jeffers.

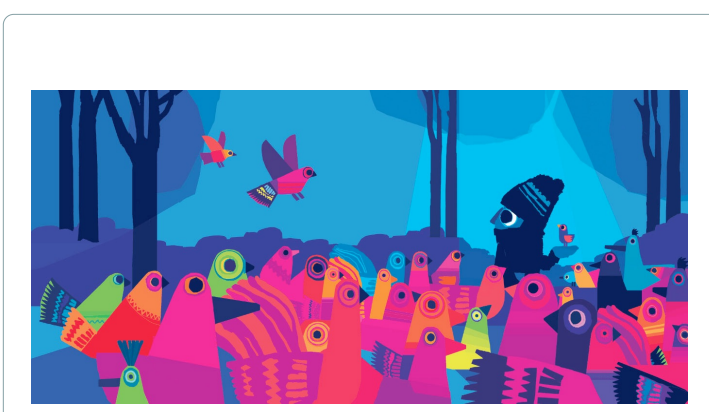

Figure 8.16

Collage is a process of assembling images from different materials. Chris Haughton used collage and digital illustration to create Shh! We Have $A$ Plan. He describes the making of his book and the details of his writing and illustration process on his blog (http://blog.chrishaughton.com/

the-making-of-shh-we-have-a-plan/). Shh! We Have

A Plan by Chris Haughton, 2014, Somerville, MA: Candlewick. Copyright 2014 by Chris Haughton.

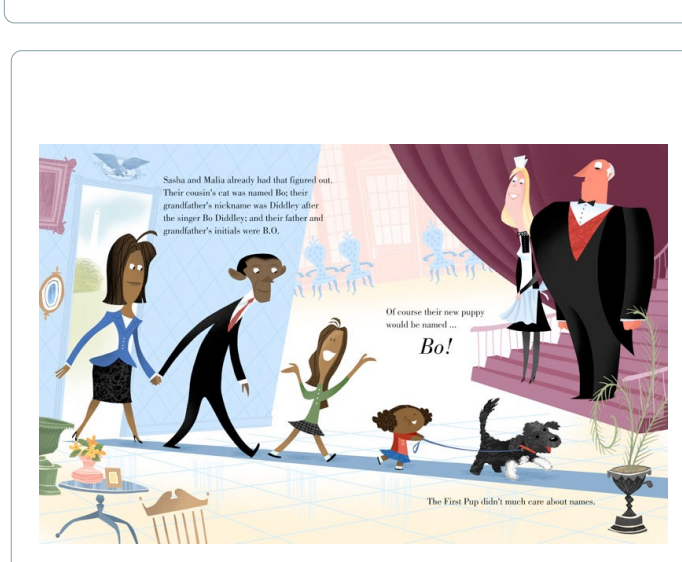

Figure 8.17

Digital (Figure 8.17)

Digital illustration is quite pervasive as many new artists are trained using digital tools. Illustrators often combine digital techniques with handmade illustration, but some work completely electronically. Bob Staake is a prolific, digital illustrator who creates children's books and much more. Read about his art and books on his website (http://www.bobstaake.com/). Image from The First Pup: The Real Story of How Bo Got to the White House by Bob Staake, 2010, New York, NY: Feiwel \& Friends. Copyright 2010 by Bob Staake. 
Gouache (Figure 8.18)

\section{Oil (Figure 8.19)}

Pastels (Figure 8.20)

Pen and Ink (Figure 8.21)

Scratchboard (Figure 8.22)

Watercolor (Figure 8.23)

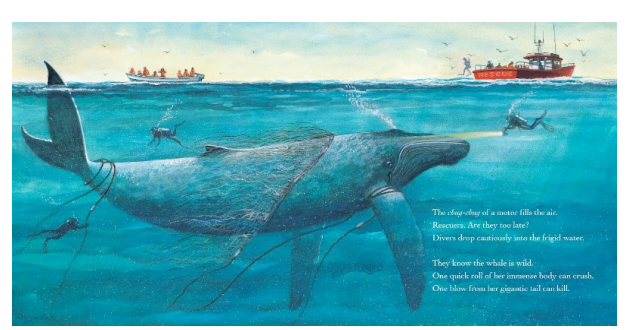

Figure 8.18

Gouache is a water-based paint that is more color-dense than watercolors. Wendell Minor creates beautiful paintings using gouache (http://www.minorart.com/childrensbooks.html). A recent example is Trapped! A Whale's Rescue by Robert Burleigh with paintings by Wendell Minor, 2015, Boston, MA: Charlesbridge. Illustration copyright 2015 by Wendell Minor.

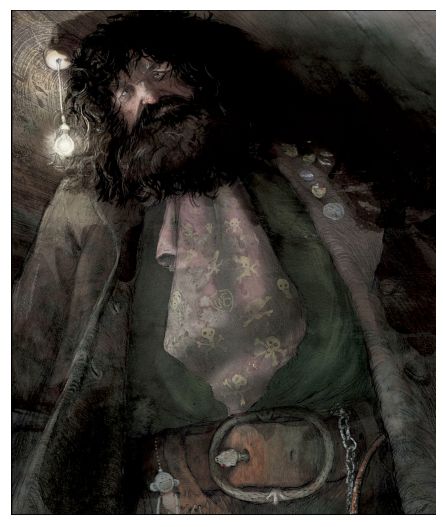

Figure 8.19

Oil paint is a slow-drying paint in which the pigment is suspended in oil. Jim Kay is an illustrator who uses oil along with other media. He was selected by J.K. Rowling to create the illustrated version of Harry Potter and the Philosopher's Stone. His illustrations allow Harry fans to revisit the story in a whole new way. Amazing! Watch a video of Jim's process (https://www.youtube.com/ watch?v=GmhDRHIix48\&feature=youtu.be). Image from Harry Potter and the Philosopher's Stone Deluxe Illustrated Edition by J.K. Rowling and illustrated by Jim Kay, 2015, London, UK: Bloomsbury Children's. Illustration copyright 2015 by Jim Kay.

\section{Figure 8.20}

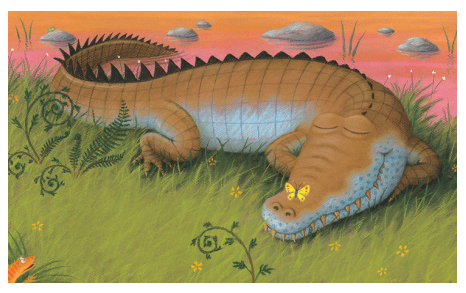

Pastels are a powdered pigment that is formed into a stick. Pastels have a powdery property similar to chalk. Lynne Chapman creates illustrations using pastels. She shares her techniques through a series of videos

(http://www.lynnechapman.co.uk/talking-about-work.php). Image from Rumble, Roar, Dinosaur! By Tony Mitton and illustrated by Lynne Chapman, 2010, New York, NY:

Macmillan. Illustration copyright 2010 by Lynn Chapman. Retrieved from https://s-media-cache-ako.pinimg.com/ originals/1d/1b/a1/1d1ba155de585d46fd7adbf64e858494.jpg.

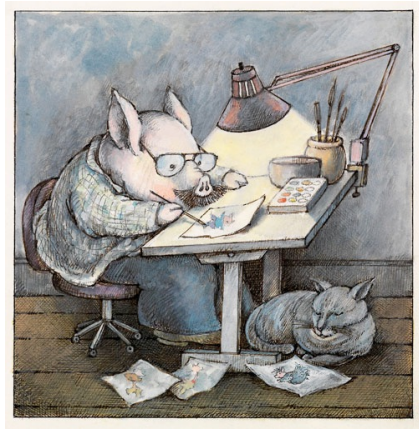

Figure 8.21

Pen, ink, and graphite are familiar media for most people; they are the writing tools we commonly use. However, in the hands of an artist, new worlds are created. Arnold Lobel illustrated some of the most memorable characters using graphite, ink, and watercolor. You might know Frog and Toad, but this is Arnold's self-portrait from The Book of Pigericks by Arnold Lobel, 1983, New York, NY: HarperCollins. Copyright 1983 by Arnold Lobel.

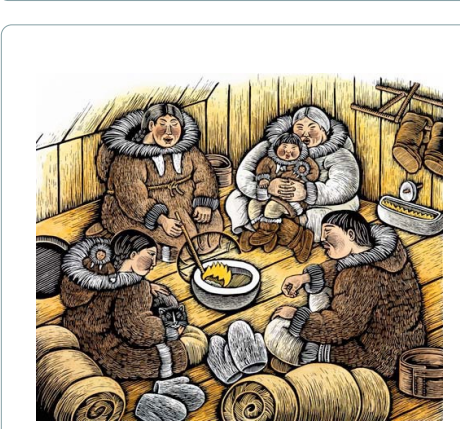

\section{Figure 8.22}

Scratchboard is an illustrative technique in which the artist uses tools to scratch into clay covered by ink. Beth Krommes shares further details and examples on her website (http:// www.bethkrommes.com/illustration/what-is-scratchboard). Image from The Lamp, the Ice, and the Boat Called Fish by Jacqueline Briggs Martin and illustrated by Beth Krommes, 2001, New York, NY: HMH Books for Young Readers. Illustration copyright 2001 by Beth Krommes.

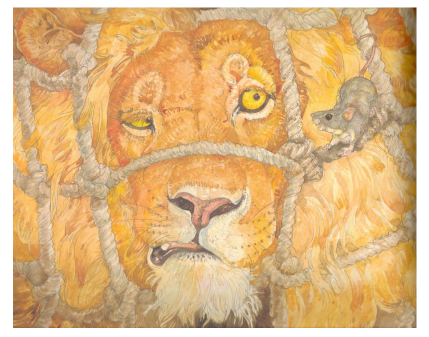

Figure 8.23

Watercolors are pigments suspended in a water-based solution. Jerry Pinkney is a master storyteller using watercolor. Most of his books include words, but The Lion and the Mouse is a wordless book. Jerry shares his process in several videos available on his website (http://www.jerrypinkneystudio.com/ frameset.html). Image from The Lion and the Mouse by Jerry Pinkney, 2009, New York, NY: Little, Brown Books for Young Readers. Copyright 2009 by Jerry Pinkney. 


\section{Getting Published}

There isn't one way to write a children's book. There isn't one way to illustrate text. Hone your craft. Seek feedback. Expect rejection. Work to accept criticism with an open mind. If children's book publishing is your passion and goal, I wish you the best of luck! It is a complicated industry. I have not published children's literature, and I can't claim insider experience. However, I have published academic texts and I have talked to many authors and illustrators. I can share their advice.

\section{Learn from Mentors}

Many years ago, scholars tried to capture the individual experiences of writers and artists in order to share their advice with novices (Cott, 1981; Murray, 1992; Wachtel, 1994). Similarly, children's book writers and illustrators published their own reflections on their composing activities to inform others about the book creation process (Paterson, 1981; Rylant, 1989). One of the most consistent resources for "letting the authors talk about their work themselves" has been The Paris Review (http://www.theparisreview.org/). Since 1953, founding editor, George Plimpton, and other contributors, interviewed prominent children's authors such as E.B. White (Plimpton \& Crowther, 1969, No. 48), P.L. Travers (Burness \& Griswold, 1982, No. 86), and Paula Fox (Broudy, 2004, No. 170). Through these exchanges, the interviewers explored the authors' childhoods and motivations for writing as well as their processes.

Mentoring and publication advice is available online. Watch out for self-promotion and those seeking financial gain. You can usually spot the artists from the con-artists, but be cautious. Here are a few examples of good advice and mentoring.

Jane Massy describes the book development process:

http://www.artistsandillustrators.co.uk/how-to/family-art/281/how-to-illustrate-achildrens-book

The Children's Literature Research Collection at the University of Minnesota presented an online exhibit about the engineering of a picture book, featuring Melissa Sweet's "Balloons Over Broadway." http://gallery.lib.umn.edu/exhibits/show/balloons-over-broadway

Allison Jay describes the book illustration process in this blog post: https://kathytemean.wordpress.com/2014/05/17/illustrator-saturday-alison-jay/

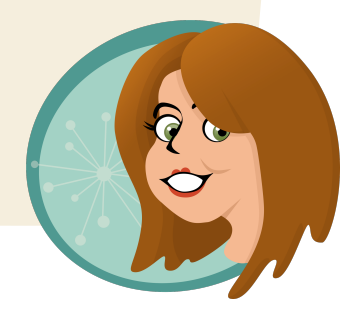


More recently, The Paris Review launched The Paris Review for Young Readers (http://www.theparisreview.org/blog/2015/04/01/the-paris-review-for-young-readers/) and featured Eric Carle as their first interviewee. This blog "offers the same caliber of fiction, poetry, art, and interviews you expect from The Paris Review, for readers age eight to twelve." Although The Paris Review blog is written for children, the creators insist that it will not condescend to children and, therefore, the blog is positioned to provide insider views about the creation of children's literature for all audiences.

Similarly, The Horn Book posts monthly Talks with Roger that feature interviews by Roger Sutton (editor-in-chief) with some of the most well-known and successful writers and illustrators in children's literature (http://www.hbook.com/talks-with-roger/).

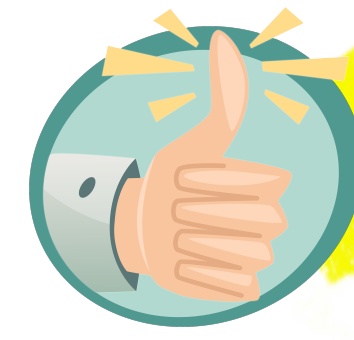

Getting published is hard work. Read interviews. Watch videos. Peruse literary magazines and websites. Learn about the art and business of children's literature.

\section{Engage in Professional Networks}

Today, aspiring authors and illustrators have unprecedented access to writers and illustrators through digital resources that provide up-close and personal accounts of children's literature creation. In addition, many authors and illustrators use social networks to interact with fans and share their illustrations outside the pages of books.

Here are some suggestions for following illustrators of children's books.

18 Illustrators to Follow on Instagram

http://www.buzzfeed.com/mallorymcinnis/follow-these-illustrators-on-instagram\#.gj2ajWgbY

Picture Book Authors \& Illustrators on Twitter

http://taralazar.com/2009/04/o8/childrens-picture-book-authors-on-twitter/

Check Out the Children's Illustrators Showcase

https://twitter.com/cillustrators

Find Information Through Author \& Illustrator Websites

Search the professional Society of Children's Books Writers and Illustrators:

http://www.scbwi.org/

Don't Follow the Pigeon

Follow Mo Willems on Twitter https://twitter.com/The_Pigeon

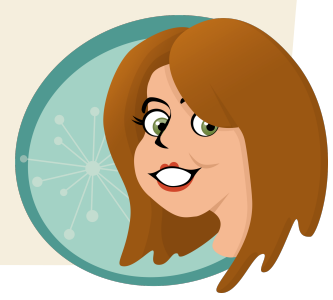


Following, liking, and friend-ing authors and illustrators is a great way for aspiring writers and illustrators to enter children's literature networks and learn who's who and what's what.

\section{Listen to Good Advice}

Publishing success is a combination of individual talent, unique ideas, dogged persistence, and luck. It's hard to capture exact measurements of an organic, flexible, and nuanced process; and, unfortunately, it's easy to be misled or fall victim to predatory agents and publishers. For very clear specifics about publishing children's books, the following resources provide helpful information:

- The Society of Children's Book Writers and Illustrators (SCBWI) is an organization for new and established authors and illustrators. SCBWI offers workshops, blogs, and services to support children's book creators. SCBWI also has regional chapters which offer critique groups, newsletters, boot camps, and networking opportunities at the local level (http://www.scbwi.org/).

- The Children's Writer's \& Illustrator's Market (CWIM) by Chuck Sambuchino, is a reference book that is published annually. The CWIM provides market and submission/contact information for book publishers, art representatives, international publishers, literary agents, contests, magazines, and conferences. The book also includes interviews with experienced writers and illustrators, interviews with debut authors and illustrators, and instructional articles and webinar links. You can buy the newest version from the publisher (Writers Digest) or from booksellers. You can also access older versions from Google Books and most university libraries (http://www.writersdigestshop.com/2016-childrens-writers-and-illustrators-market).

- The Artist's \& Graphic Designer's Market by Mary Burzlaff Bostic is a reference book for those who want a career in fine art, illustration, or graphic design. Similar to the CWIM, the Artist's \& Graphic Designer's Market publishes interviews and insider information. It also provides contact information for art resources including galleries, book publishers, greeting card companies, and other outlets (http://www.amazon.com/2016-Artists-Graphic-Designers-Market/dp/144034261X).

- Neil Gaiman offers very specific advice about getting published (http://www.neilgaiman.com/FAQs/Advice_to_Authors). 
- Neil Gaiman also offers very good advice about getting an agent (http:// journal.neilgaiman.com/2005/o1/everything-you-wanted-to-know-about.asp).

- Find out the difference between traditional publishing, vanity publishing, and selfpublishing (http://theworldsgreatestbook.com/self-publishing-vanity-publishing/).

Get informed. Stay informed. Follow up and follow through. Although many resources provide good advice, each situation is different and you must exercise due diligence to protect yourself and make decisions in your best interest.

\section{Where Do Authors and Illustrators Get Their Ideas?}

Ideas are peculiar. They are ephemeral and permanent, fluid and specific. They come from nowhere and from everywhere. As Neil Gaiman wrote, "Where do I get my ideas from? I make them up. Out of my head" (http://www.neilgaiman.com/Cool Stuff/Essays/Essays By Neil/ Where_do_you_get_your_ideas\%3F).

If you have a good idea for a children's book, it's important to know if it's been done before. To find out, do your homework! Read, look, write, and draw.

\section{Read, Read, Read}

Authors and illustrators overwhelmingly suggest that aspiring book creators need to read (http://writeforkids.org/2014/05/start-here-writing-for-children-step-one/). Reading literature is the writer's or illustrator's greatest tool. Reading other books gives creators ideas in the forms of images, memories and words. Reading also allows authors and illustrators to study language, phrasing, story structure, and design. Many authors and illustrators have been inspired by the work, style, or voice of another creator.

\section{Look, Look, Look}

Writers and illustrators also get ideas by paying attention to the world around them. Through personal interactions and conversations, many children's book creators find ideas in their daily encounters. Ideas can also arrive from faraway places and from different periods in time. Events or stories that are reported on the news or in newspapers can trigger a writer or illustrator into action. In case you missed this earlier, Oliver Jeffers perfectly explains idea sources (https://vimeo.com/57472271). 


\section{Write, Write, Write or Draw, Draw, Draw}

Many writers keep personal journals, blogs, or diaries. Others may use Twitter, Instagram, and other sites to record words, images, and phrases. Some illustrators keep digital or paper sketch pads. Others use nothing at all. Through multiple text forms or mental remembering, writers and illustrators collect and curate their thoughts, feelings, observations and reactions to daily events. They may also store dreams and recollections in some tangible way. Many children's book creators state that specific words and passages will enter their minds and never leave. Some writers rely on their memories to hold these words, others put them in safe paper and digital places.

Whether writing or illustrating, it is hard to trace a creator's ideas. We rely on their personal recollections to know what they were thinking, who they've read or watched, or what they know. We can also try some idea sleuthing ourselves!

\section{Whose idea is it anyway? Big ideas in Jurassic Park, Jumanji, and The Cat in the Hat}

By Anne W. Anderson

The June 2015 release of Jurassic World, the fourth movie in the Jurassic Park series, takes the dinosaur-cloning-breeds-disaster premises of the previous movies (Jurassic Park, 1993; The Lost World: Jurassic Park, 1997; and Jurassic Park, III, 2001) a step further. Instead of just cloning dinosaurs from prehistoric DNA, Jurassic World explores the idea of genetically engineering dinosaurs. Unlike the previous three movies, which were based on Michael Crichton's novels Jurassic Park (1990) and The Lost World (1995), Jurassic World was not based on a novel. Crichton, who died in 2008 and who wrote about genetic engineering in his 2006 book Next (Figure 8.24), didn't link genetic engineering to dinosaurs. Instead, after some legal wrangling, the screen credits read:

"Screenplay by Rick Jaffa \& Amanda Silver and Colin Trevorrow \& Derek Connolly; Story by Rick Jaffa \& Amanda Silver; Based on characters created by Michael Crichton" (Robb, 2015, para. 1). Here is how the Internet Movie Database lists the writers on each of the four movies (Table 1).

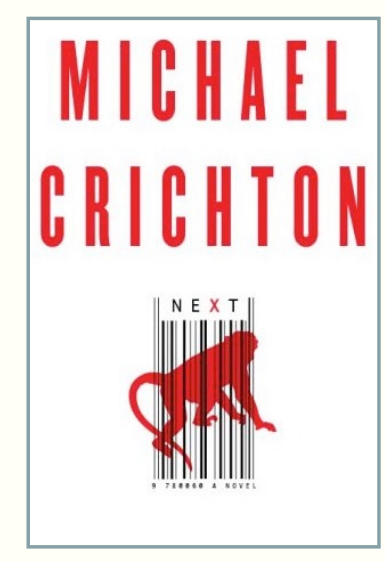

Figure 8.24

Michael Crichton wrote about genetic engineering in his book, Next by Michael Crichton, 2006, New York, NY: HarperCollins. Cover copyright 2006 by HarperCollins. 
Table 1. This table shows how the idea for the Jurassic Park films began with Michael Crichton's novels but then took on a life of its own as other people built other stories around the characters Crichton created.

\begin{tabular}{|c|c|}
\hline Film & Writing Credits \\
\hline $\begin{array}{l}\text { Jurassic Park } \\
\text { (1993) }\end{array}$ & $\begin{array}{l}\text { Novel by Michael Crichton; Screenplay by Michael Crichton and David } \\
\text { Koepp } \\
\text { http://www.imdb.com/title/tto10729o/ }\end{array}$ \\
\hline $\begin{array}{l}\text { The Lost World: } \\
\text { Jurassic Park } \\
\text { (1997) }\end{array}$ & $\begin{array}{l}\text { Novel by Michael Crichton; Screenplay by David Koepp } \\
\underline{\text { http://www.imdb.com/title/tto119567/ }}\end{array}$ \\
\hline $\begin{array}{l}\text { Jurassic Park III, } \\
2001\end{array}$ & $\begin{array}{l}\text { Based on characters created by Michael Crichton; Written by Peter } \\
\text { Buchman and Alexander Payne \& Jim Taylor* } \\
\underline{\text { http://www.imdb.com/title/tto163025/fullcredits?ref_=tt_ov wr\#writers }}\end{array}$ \\
\hline $\begin{array}{l}\text { Jurassic World } \\
\text { (2015) }\end{array}$ & $\begin{array}{l}\text { Screenplay by Rick Jaffa \& Amanda Silver and Colin Trevorrow \& Derek } \\
\text { Connolly; Story by Rick Jaffa \& Amanda Silver; Based on characters } \\
\text { created by Michael Crichton http://www.imdb.com/title/tto369610/ } \\
\text { fullcredits/ }\end{array}$ \\
\hline \multicolumn{2}{|c|}{$\begin{array}{l}\text { *According to the Writers Guild of America (2015), the ampersand (\&) between } \\
\text { names indicates a team of writers. When more than one team works together or when } \\
\text { individual writers work together, the word "and" is used. (Theatrical Credits } \\
\text { Procedures A,1D) }\end{array}$} \\
\hline
\end{tabular}

So whose idea was Jurassic World? Not listed in the writing credits are the directors, Steven Spielberg (Jurassic Park and The Lost World: Jurassic Park), Joe Johnston (Jurassic Park III), and Colin Trevorrow (Jurassic World) who "wrote" the words of the screenplay onto film. Money-maybe millions of dollars-and reputations are at stake in who is credited with what in Hollywood films. But is an idea ever just the product of one person's brain? And what about other types of adaptations such as theme parks, video games, and toys based on books and films? Whose ideas are they? 
Another book that became a 1995 film-also directed by Joe Johnston, who later directed Jurassic Park III-that became a board game, video game, television series, and more-is Chris Van Allsburg's Jumanji, which won the Caldecott Medal (1981) for its illustrations. Van Allsburg's blackand-white illustrations show the reader the story of Judy and Peter and a troublesome board game, Jumanji, from various perspectives. At one point, the reader seems to be on the floor looking up at Peter who is kneeling on a chair as he watches his train travel underneath the chair and around the room (p. 2) (Figure 8.25). After the children, whose parents have gone out, have become bored playing with their toys, the reader is positioned at an upstairs window watching the children leave the yard for the park across the street (p. 4). Next, the reader watches from above as the children begin to play the board game they have found in the park (p. 6) (Figure 8.26).

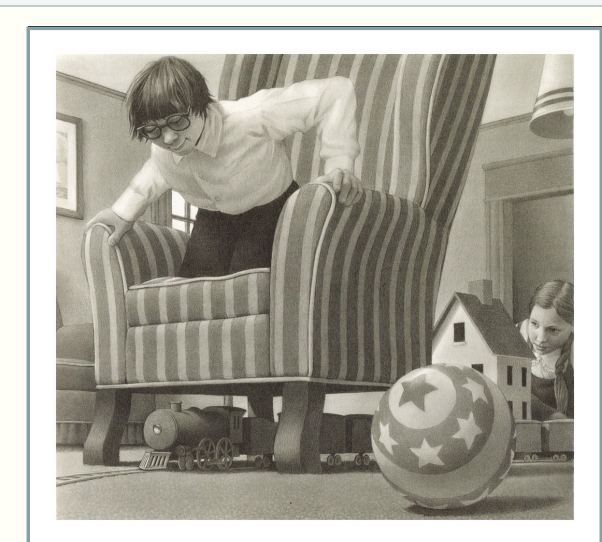

Figure 8.25

Peter, a main character in Jumanji, kneels on a chair as he watches his train travel underneath the chair and around the room. Image from Jumanji by Chris Van Allsburg, 1981, New York, NY: Houghton Mifflin. Copyright 1981 by Chris Van Allsburg.

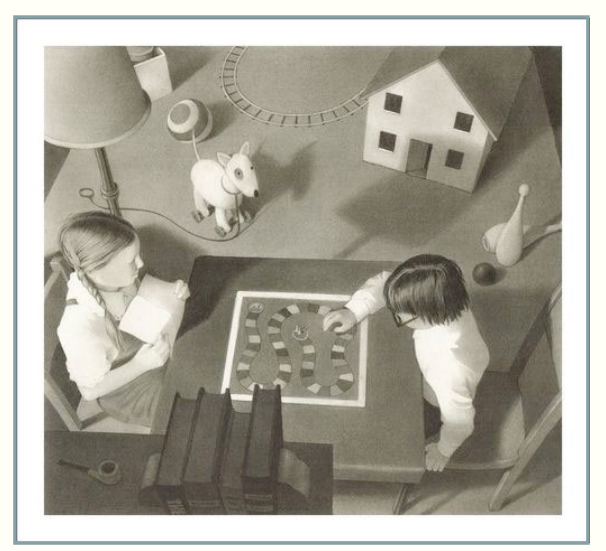

Figure 8.26

The reader watches from above as Judy and Peter begin to play the board game they have found in the park. Image from Jumanji by Chris Van Allsburg, 1981, New York, NY: Houghton Mifflin. Copyright 1981 by Chris Van Allsburg.

In the book, the story is only about Judy and Peter whose parents have left them at home with instructions to keep the house tidy. There is no Alan Parish who had argued with his parents and was running away from home when he was sucked into the game a quarter of a decade earlier. Only when the film version of Judy and Peter, orphans living with their aunt, find the game and resume play is Alan freed from the Jumanji jungle. But he is no longer a child and the house he once knew as home is no longer his. The game in the book says it is "especially designed for the bored and restless" (p. 5), not, as the game in the movie says, "for those who seek to find a way to leave their world behind." Unlike in the movie, where the giant mosquitoes, stampeding rhinos, and other creatures leave the house and wreak havoc on the town, all the adventures occur inside the house in the book version. Whereas in the movie Van Pelt is a murderous hunter, the unnamed jungle guide in the book is merely confused and lost. 
How and why did the movie change so much? Chris Van Allsburg is listed in the screen credits as helping to write the screen story that was based on his book (IMDB). But the movie exaggerates what happens, heightening the suspense and suggesting that, no matter what people do to try to get rid of the game, the game is alive and waiting for a new set of victims. The movie also adds another element not in the book: a romance between the adult Alan, played by Robin Williams, and Sarah Whittle, played by Bonnie Hunt.

Although books and movies are viewed as the same story, they are not. Books aren't movies. Movies aren't books. We are seeing and experiencing narratives through two different media.

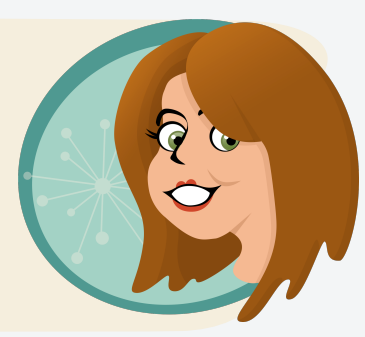

Joel Chaston (1997), writing about children's books adapted to films, noted that "classical Hollywood narration" (p. 14), meaning the plot lines in films that Hollywood has found to be successful, often combine "[a]dult heroes. . . whose narrative progress ranges from a restoration of the status quo ante to the development of a completely new order of things, frequently coupled with a second plot trajectory that works toward the fulfillment of heterosexual romance" (p. 14). Romantic love, to many people, seems an "inappropriate" storyline involving children, and Chaston said, "certain aspects of psychological realism appear to dictate a desire [for child protagonists] to return to a more familiar and manageable environment such as home" (p. 14). Hollywood reflects a more typical adult understanding of what is considered appropriate for children, whereas children's books "frequently delight in subverting precisely these conventions" (p. 13). In other words, when Hollywood writers make a movie of a children's book, they either tweak the plot so the child realizes he/she has misjudged his/her parents and wants nothing more than to get safely home-with all the word implies-or they add an adult romance, or they do both.

Anne brings up an interesting point here. Think about it, do the professionals who make movies - the writers, directors, actors, casting agents, camera crewhave expertise in "childhood" or degrees in child-focused fields of study? Do they understand children's social, emotional, cognitive and physical developmental trajectories? Of course not. They may have children in their own homes, but they haven't studied filmmaking from a child's perspective. Film schools aren't focused on children so the individuals who create films bring adult sensibilities to the product. They add adult backstories.

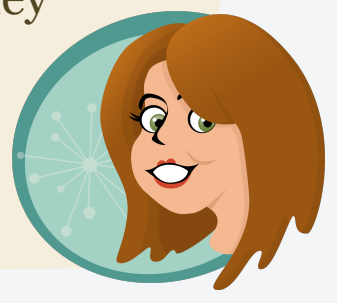


In the case of Jumanji, they did both. Instead of a bored Judy and Peter looking for a little excitement, Hollywood adds Alan who was beaten up by bullies who took his bike, has fought with his parents, and is in the process of running away. Just as he gets ready to leave, however, he is sidetracked by the game ... and by Sarah, a schoolmate, who has found and returned his bike. When Alan returns after years of being rumored as either missing or murdered, he wants nothing more than to find his parents, i.e., to return safely "home." He also reconnects with a now grown-up Sarah, with predictable results. Cinematically, the film Jumanji has much in common with the Jurassic Park films. In addition to being directed by Joe Johnston, who also directed Jurassic Park III, the film version of Jumanji features hordes of flying, crawling, and stampeding animals who, like those in Jurassic Park, have been taken out of their original "natural" setting-prehistoric times for the Jurassic-era dinosaurs and Africa for the modern-era beasts-by the plot devices of science fiction or fantasy. Additionally, Jurassic Park was the first film to use computer-generated imagery in some shots; Jumanji was the second film to use CGI.

The Jumanji film plot also echoes elements of the plot of Where the Wild Things Are by Maurice Sendak.

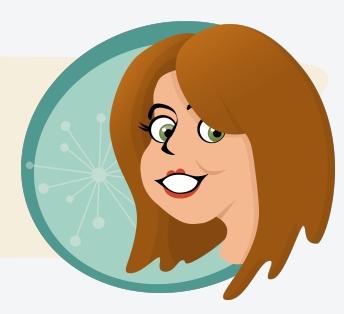

The ideas in the book version of Jumanji, however, have more in common with an earlier story, one that also features a brother and sister left alone at home (Figure 8.27), this time on a cold, rainy day that leaves them sitting and looking out the window. When the boy says, "How I wish we had something to do" (Seuss, 1957, p. 4), they hear a "BUMP!" (p. 5). In walks the Cat in the Hat (Figure 8.28) who proceeds to cause all sorts of mayhem with his games and tricks-and with his own mini-horde of creatures, i.e., Thing One and Thing Two, who fly kites in the house and get into the mother's bedroom. In the book version of Jumanji, it is a lion that chases Peter into the parents' bedroom and is trapped there by Peter's quick thinking.

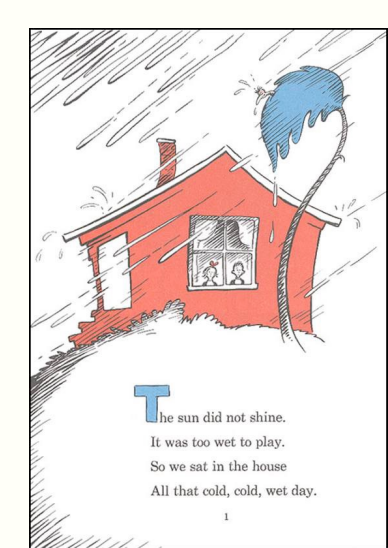

Figure 8.27

The Cat in the Hat features a brother and sister left alone at home, on a cold, rainy day. The Cat in the Hat by Dr. Seuss, 1957, New York, NY: Random House. Copyright 1957 by Dr. Seuss.

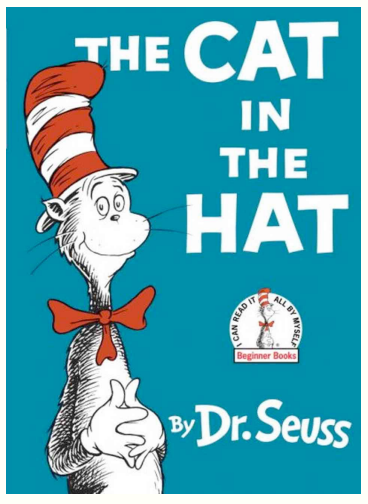

Figure 8.28

The Cat from The Cat in the Hat by Dr. Seuss, 1957, New York, NY: Random House. Copyright 1957 by Dr. Seuss. 
Both Jumanji and The Cat in the Hat feature "bored and restless" (Van Allsburg, 1981, p. 5) children whose parents have left them at home with either explicit instructions to tidy up (Jumanji) or with the expectation that they will (The Cat in the Hat) behave, i.e., that they will keep the house tidy. Far from yearning to be safely at home, the children are home. As most children begin to do, they long for the excitement they think is to be found in the outside, grownup world. Van Allsburg and Seuss grant their wishes, providing mayhem of a magnitude to satisfy even the most skeptical child. Both books even invade the parents' sacred domains-their bedrooms-all without the parents' knowledge. Both books end with all the creatures gone from the house and everything tidy by the time the adults return home. Both mothers ask what the children did while the adults were gone. Peter (Jumanji) begins to tell his parents about the adventures, but the adults laugh and think he has just been dreaming. Sally and her brother (The Cat in the Hat) just look at each other, trying to decide what to say. Seuss ends his story by asking the reader, "Should we tell her about it? Now, what SHOULD we do? Well ... What would YOU do if your mother asked you?” (p. 61).

Van Allsburg and Seuss depict children who have been lured by a board game or by a Cat with a game into a kind of wild rampage. Both authors subvert the adult expectations that children want to be safely at home and that children obey instructions when they are left alone by showing what happens when the adults are absent. Seuss, in particular, draws attention to what the children "SHOULD" do by repeating the word and by writing it once in all capital letters. But then he turns the question back to the reader, suggesting, perhaps, that the reader wouldn't tell, either.

Did Van Allsburg get the idea for his story from Dr. Seuss? Where did Dr. Seuss get the idea for his story?

If we go way back, we might think about the myth of Pandora, who disobeyed Zeus, opened a jar he had told her not to open, and released all the evils into the world. Or we might think about Eve in the Garden of Eden disobeying the instruction not to eat of the fruit of the Tree of the Knowledge of Good and Evil-or, to flip the story, about Eve and Pandora longing to know what would happen if they went against or subverted what the person in charge said to do. Psychologist Carl Jung's theory about the "collective unconsciousness" suggests all people and all cultures share common story patterns, like the similarities between the stories of Pandora and Eve. Does that mean there is no truth in them? Or does it mean there is a truth that is too big to be confined to a single story? Is that why so many stories seem to be retelling the same few big ideas? 
Jumanji and The Cat in the Hat seem to tell similar stories about the conflict between parents and children and between what we should do and what we want to do, but what about Jurassic Park? In some sense, Michael Crichton and the writers who have followed him seem to be depicting some scientists as bored with the conventional ways of doing things and who are curious about what would happen if they tried something different. Unlike in Jumanji and The Cat in the Hat, however, the resulting death and destruction are very real and they don't go away because the game never really ends.

In the end, it may not matter whose idea it is or who had it first. Instead, what matters is that we stop to listen and to think deeply about the stories we hear and see and to think about the big ideas contained in them.

As you read stories and watch films, think about the big ideas the authors are presenting. Also think about the ways in which the illustrators or visual artists visualize their ideas. Whose perspective is told? How are you positioned as the reader?

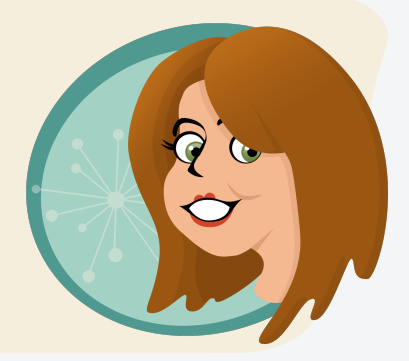

\section{Take Offs, Spin Offs, and Paraphernalia}

As Anne delineated, ideas are hard to trace. Origins are not always clear. For these reasons, copyright law exists. Permissions are expensive, but business entities are willing to pay the price for intact fan bases and guaranteed sales.

Children's literature often functions as the source text for movies, toys, clothing, games, and apps. Walt Disney famously mined children's literature for his most successful animated films. Other movie studios followed suit and have created films to follow a book's success. A successful film will yield a toy line, a clothing line, and a series of games, puzzles, apps and licensed products. Even unsuccessful films will yield product lines. 
Here is a short selection of children's books that have accompanying adaptations. Peruse the list and choose your favorite to read, watch, or play.

\section{Shrek}

Book: Shrek! by William Steig (Figure 8.29)

- Steig, W. (1990). Shrek!. New York: Farrar, Straus, Giroux.

Movie: Shrek by Dreamworks

- Adamson, A., Jenson, V., Warner, A., Williams, J. H., Katzenberg, J., Elliott, T., Rossio, T., ... DreamWorks Home Entertainment (Firm). (2006). Shrek. Glendale, CA: DreamWorks Animation.

Apps: Pocket Shrek (2015) by No Yetis Allowed.

- https://itunes.apple.com/us/app/pocket-shrek/ id 886216658 ? $\mathrm{mt}=8$

\section{Peter Pan}

Play: Peter Pan in Kensington Gardens by J.M. Barrie

- Barrie, J. M., \& Rackham, A. (1910). Peter Pan in Kensington gardens. New York: C. Scribner's Sons.

Book: Peter and Wendy by J.M. Barrie (Figure 8.30)

- Barrie, J. M., \& Oliver Wendell Holmes Collection (Library of Congress). (1911). Peter and Wendy. New York: Charles Scribner's Sons.

Movie: Hook by Amblin Entertainment, TriStar

- Spielberg, S., Hart, J. V., Marmo, M. S., Castle, N., Kennedy, K., Marshall, F., Molen, G. R., ... Columbia TriStar Home Video (Firm). (2000). Hook. Burbank, CA: Columbia TriStar Home Video.

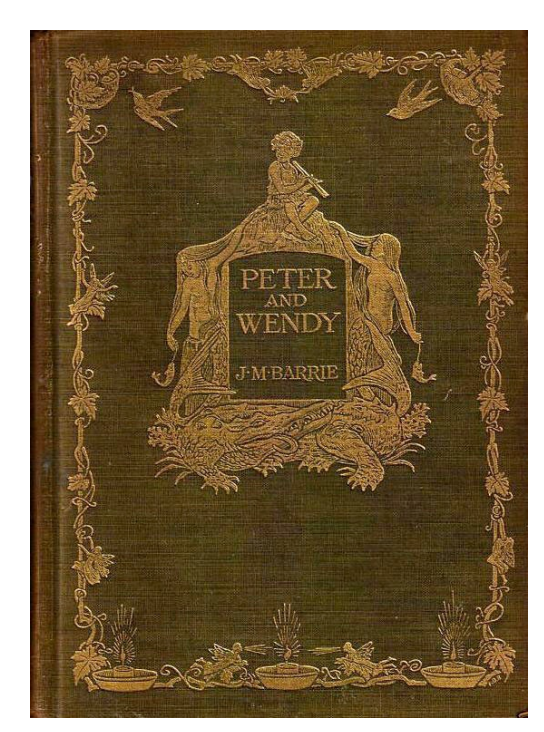

Figure 8.30

Peter Pan: The Boy Who Wouldn't Grow Up by J.M. Barrie, 1904, London, England: Hodder \& Stoughton. Copyright 1988 by Great Ormond Street Hospital. 
Movie: Peter Pan by Walt Disney Co.

- Disney, W., Luske, H. S., Geronimi, C., Jackson, W., Driscoll, B., Beaumont, K., Conried, H., ... Buena Vista Home Entertainment (Firm). (2007). Peter Pan. Burbank, CA: Walt Disney Home Entertainment.

Movie: Pan by Dune Entertainment

- Wright, J., Fuchs, J., Jackman, H., Hedlund, G., Mara, R., \& Warner Home Video (Firm),. (2015). Pan.

eBook: Peter Pan Adventures (2015) by TabTale LTD.

- https://itunes.apple.com/us/app/peter-pan-adventures-classic/id588311104?mt=8

\section{Winnie the Pooh}

Book: Winnie the Pooh by A.A. Milne (Figure 8.31)

- Milne, A. A., Milne, A. A., Milne, A. A., \& Shepard, E. H. (1957). The World of Pooh: The complete Winnie-the-Pooh and the House at Pooh Corner.

Movie: Winnie the Pooh by Walt Disney Co.

- Milne, A. A., Milne, A. A., Anderson, S., Hall, D., Del, V. P., Spencer, C., Lasseter, J., ... Walt Disney Studios Home Entertainment (Firm). (2011). Winnie the Pooh. Burbank, CA: Walt Disney Studios Home Entertainment.

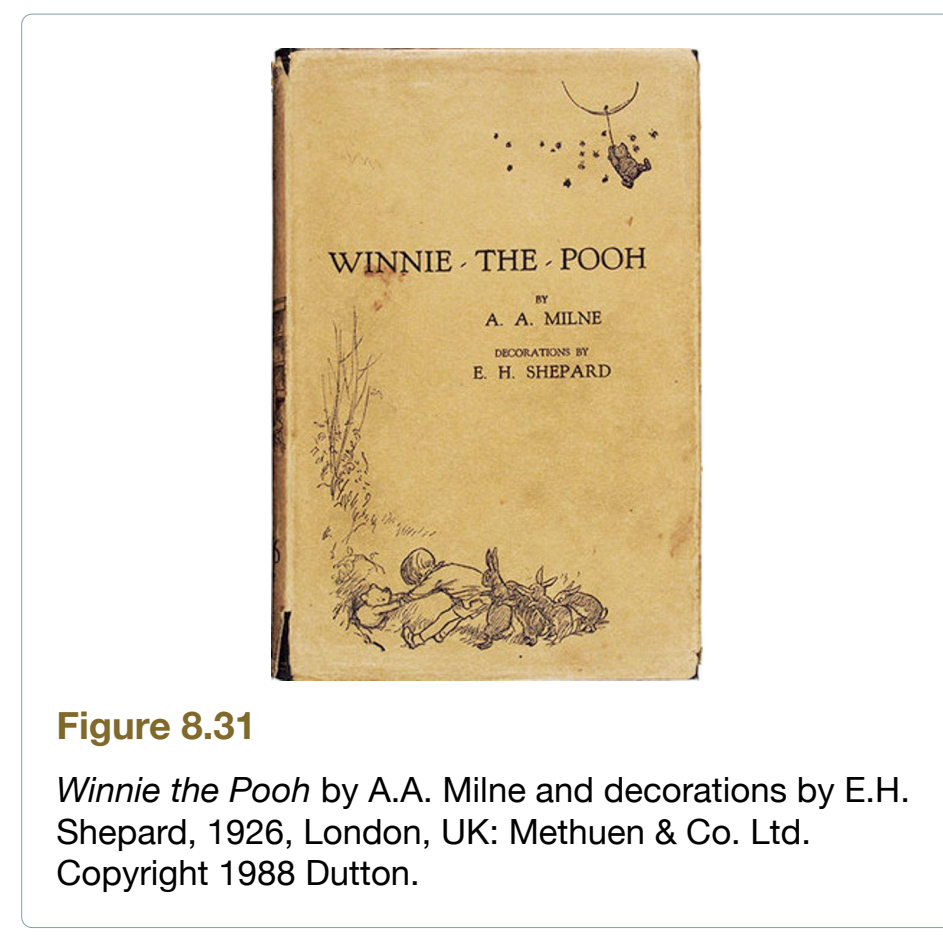

Television: The New Adventures of Winnie the Pooh by American Broadcasting Co.

- Clemmons, L., Lounsbery, J., Reitherman, W., Walmsley, J., Cabot, S., Winchell, P., Milne, A. A., ... Buena Vista Home Entertainment (Firm). (2013). The many adventures of Winnie the Pooh. United States: Buena Vista Home Entertainment.

Apps: Letters with Pooh (2015) by Disney

- https://itunes.apple.com/us/app/letters-with-pooh/id535661652?mt=8 


\section{Mary Poppins}

Book: Mary Poppins by P.L. Travers (Figure 8.32)

- Travers, P. L., \& Shepard, M. (1962). Mary Poppins. New York: Harcourt, Brace \& World.

Movie: Mary Poppins by Walt Disney Co.

- Stevenson, R., Walsh, B., DaGradi, D., Andrews, J., Van, D. D., Tomlinson, D., Johns, G., ... Buena Vista Home Entertainment (Firm). (2004). Mary Poppins. Burbank, Calif: Walt Disney Home Entertainment.

Movie: Saving Mr. Banks by Walt Disney Co.

- Hancock, J. L., Marcel, K., Smith, S., Owen, A.,

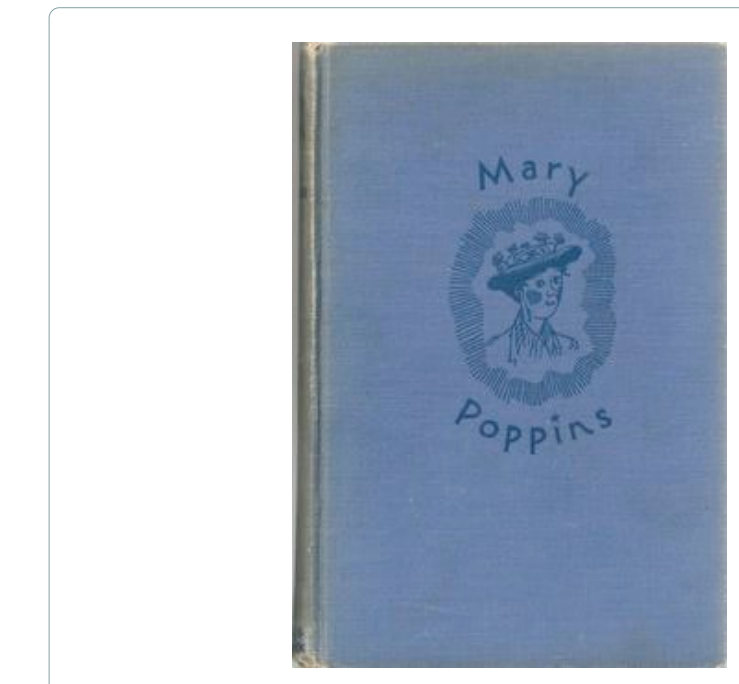

Figure 8.32

Mary Poppins by P.L. Travers and illustrated by Mary Shepard, 1934, London, UK: HarperCollins. Copyright 1962 by P.L. Travers.

Collie, I., Steuer, P., Newman, T., ... Buena Vista Home Entertainment (Firm),. (2014). Saving Mr. Banks. Burbank, Calif: Walt Disney Home Entertainment.

Toy: Mary Poppins Pop Vinyl

- http://www.amazon.com/Funko-POP-Disney-Poppins-Figure/dp/BooBV1P5Ho/ref=sr_1__?s=toys-andgames\&ie=UTF8\&qid=1451846742\&sr=1-1\&refinements=p_lbr_characters_browse-bin\%3AMary+Poppins

Are children's books an adequate basis for films and other adaptations? Do you expect the film to stay true to the book or vary from the original? Two researchers, Amit Joshi and Huifang Mao decided to study the relationship between best-selling books and motion picture adaptations. Joshi and Mao analyzed over 700 movies and found that book-based movies performed better at the box office on the opening weekend than non-book movies. They also discovered that "the opening weekend performance of book-based movies is positively driven by book equity, book-movie similarity, and recency between the book's peak equity and movie release" (Joshi \& Mao, 2012, p. 558). In other words, if audiences loved the book, they want the movie to bring the book to life.

This may be why Steven Spielberg declined to direct Harry Potter. He wanted to make Harry an animated film and he ended up backing out. He stated:

I purposely didn't do the Harry Potter movie because for me, that was shooting ducks in a barrel. It's just a slam dunk. It's just like withdrawing a billion dollars and putting it into your personal bank accounts. There's no challenge http://www.hollywood.com/general/quote-of-the-day-spielberg-on-not-making-harry-potter-57179290/ 
Just like the artists and writers who create children's literature, movie directors and actors bring a level of interpretation to their adaptations. When the book is just like the movie, some of the creative, interpretive work is reduced in favor of consistency with the original. As mentioned in a previous chapter, young children like to hear the same stories over and over again. I guess the same is true for older children and adults as well. The dolls, games, toys, costumes, and other paraphernalia function as reminders of the original and allow each of us to enter the story through new modes. Once there, we like things to be as we expect-close to the "original" idea.

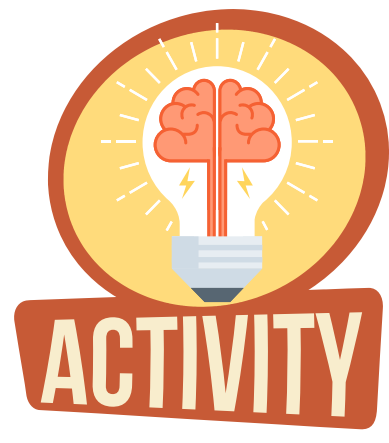

1. Choose your favorite piece of children's literature published within the last three years. I selected the three-year time frame in the hopes you find a book without other adaptations or sequels.

2. Create an artistic response to the book. Choose one of the following. Click on the links to see samples and tutorials:

\section{- Make a pop-up book}

- Watch this to see a sample:

- You definitely want to click here: http://wp.robertsabuda.com/make-your-own-pop-ups/

- https://www.youtube.com/watch?v=oXNVgoVf_pU

\section{- Create a movie trailer or short film}

- https://www.youtube.com/watch?v=yT9V2aN8OYQ

- https://www.youtube.com/watch?v=t1emxcttgKE

\section{- Develop a line of toys}

○ http://www.babble.com/home/keep-it-handmade-23-diy-toy-projects/

- Make the toys and take pictures.

\section{- Cast the movie}

- How to: http://www.howcast.com/videos/60027-How-to-Make-Your-First-Movie-Phase-3-Casting

- Complete a casting sheet.

\section{- Create a movie poster}

○ http://bighugelabs.com/poster.php

○ https://www.lucidpress.com/pages/examples/free-online-poster-maker

Why did you choose this medium? How did your product connect to or diverge from your reading of the book? Did this product give you any insight into the characters, the plot, the writing style, the illustrations, etc.? Any negative impressions? 


\section{Please, Sir. I Want Some More.}

In the words of Oliver Twist, audiences, and therefore, publishers, "want more" of a good thing. Audiences read a book and they want the author to write a sequel. Audiences read a book and they wait for the movie to premiere-even though most readers will find the book is better. When readers find a book they love, the publishers do not have to wait for a movie production; they search for similar plots, characters, and themes to push to publication. When a book is successful, trends follow suit.

Although Twilight was not the first vampire series, it sparked a trend in the publication of monster fantasy. The Hunger Games was not the first dystopian novel but it initiated a resurgent interest in dystopian fiction. Success attracts copycats, adaptations, and paraphernalia.

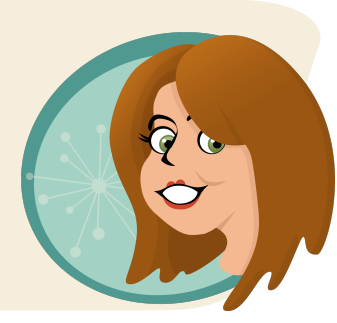

The repetitive occurrence of books, adaptations, and marketing paraphernalia give off the impression that writing and illustrating books can be bottled and sold. Many people believe if they can come up with "one great idea" the book and its successive adaptations will lead to fortunes.

As Neil Gaiman wrote:

The Ideas aren't the hard bit. They're a small component of the whole. Creating believable people who do more or less what you tell them to is much harder. And hardest by far is the process of simply sitting down and putting one word after another to construct whatever it is you're trying to build: making it interesting, making it new (http://www.neilgaiman.com/Cool_Stuff/Essays/Essays_By_Neil/Where_do_you_get_your_ideas\%3F).

Children's book writing and illustrating are creative enterprises that are focused on creating new literary, aesthetic objects-new characters, novel ideas, different plots, persuasive arguments, or unique presentations of content. Children's book publishing and product marketing are businesses-businesses focused on providing goods and services for a profit and occasionally not-for-profit. A peek behind the scenes of the children's book industry often reveals a cookie-cutter sameness that business processes have brought to bear on what begins as compositional art and turns it into product sales. Don't get me wrong, the writers and artists want to make money too. However, the children's book publishing engine is trendy, regimented, and focused on tested models and proven results, until something new comes along (self-publishing, fanfiction, Netflix, literary talent, artistic skill) and recalibrates the system. Keep these competing agendas in mind as you read children's literature. Understand the impact on the process and product when business, literature, and art combine. 


\section{TEXTUAL TENDENCEES AND OPEN AND CLOSE READINGS}

\section{SECTION 3}

